\title{
Variation and evolution of alkaloid complex in yellow lupine (Lupinus luteus L.) during domestication
}

\section{WIKTOR SWIĘCICKI and KONRAD JACH}

Poznańska Hodowla Roślin, ul. Palacza 134, 60-278 Poznań, Poland

(Received: September 3, 1979)

Abstract

\begin{abstract}
A colection of 178 primitive and cultivated forms of Lupinus luteus was analysed with respect to composition and level of alkaloids in seeds. A considerable quantitative and qualitative variation in alkaloids was found in the analysed forms. All analysed primitive forms, not cultivated in Central Europe, contained gramine and lupinine; the majority had sparteine as well. Contrary to the common opinion, yellow lupine has three basic alkaloids, i.e. gramine, lupinine and sparteine. Moreover, a lange number of primitive forms showed traces of unidentified alkaline compounds with alkaloid characteristics.

It appears that in the course of introduction of yellow lupine to Central Europe, the composition and level of its alkaloids have been gradually changing. Their reproduction and natural selection remarkably decreased the number of forms containing gramine as well as the total level of alkaloids in seeds.

Cross breeding and screening for low alkaloid bearing forms significantly decreased the total level of gramine as well as the number of forms containing gramine and almost entirely eliminated traces of unidentified alkaloids. One new form was found to have sparteine and only a little of lupinine (total level of alkaloids $0.04 \%$ ).
\end{abstract}

\section{INTRODUCTION}

Much attention has hitherto been paid to yellow lupine alkaloids. However, results of studies published do not include the considerable range of variation represented by primitive plants of this species. Determination of the overall composition of alkaloids and of their level is of great importance both from the theoretical and practical point of view. Search for resistance characters and profitable yield parameters involves increasing number of primitive forms used as components in crosses.

The papers concerning lupine (B a r b cki, 1952; $\mathrm{Hackbarth}$ 
and Troll, 1956; Maisurian and Atabiekova, 1974) pointed to the presence of two basic quinolizidine alkaloids, viz. lupinine $\left(\mathrm{C}_{10} \mathrm{H}_{19} \mathrm{ON}\right)$ and sparteine $\left(\mathrm{C}_{15} \mathrm{H}_{26} \mathrm{~N}_{2}\right)$ in yellow lupine seeds. Application of new analytical methods promoted finding trace amounts of other unidentified alkaloids ( $\mathrm{Sch}$ w a z e and $\mathrm{Hackbarth}$, 1957). Similarly, R eifer et al. (1960) reported lupinine, sparteine and other unidentified alkaloid bases in yellow lupine seeds. W i e w i órow ski and Bratek (1960) suggested that traces of alkaloids with Rf lower than that of sparteine are artefacts. Mironienko (1975) confirmed the presence of traces of an unknown alkaloid in yellow lupine seeds with Rf lower than that of sparteine, besides sparteine and lupinine. Prior to the above cited reference Wiewiórowski and Podkow in s k a (1967) and S p a r a t o r e (1964) had identified in yellow lupine a third alkaloid gramine $\left(\mathrm{C}_{11} \mathrm{H}_{14} \mathrm{~N}_{2}\right)$ - a derivative of indol.

$\mathrm{J} \mathrm{a} \mathrm{c} \mathrm{h} \mathrm{(1975)} \mathrm{provided} \mathrm{evidence} \mathrm{on} \mathrm{the} \mathrm{presence} \mathrm{of} \mathrm{gramine} \mathrm{besides}$ quinolizidine alkaloids in seeds of several hybrids derived from crosses with primitive Mediterranean forms and in seeds of certain cultivated pasture varieties; gramine considerably increased the total level of alkaloids in seeds. With a view to carry out further detailed studies $\mathrm{J} \mathrm{a} \mathrm{c} \mathrm{h} \mathrm{and} \mathrm{J} \mathrm{a} \mathrm{ch} \mathrm{(1976)} \mathrm{elaborated} \mathrm{a} \mathrm{colorimetric} \mathrm{method} \mathrm{for} \mathrm{quanti-}$ tative determination of gramine. It is generally assumed that sparteine and lupinine are highly toxic (W ier zchowsk i, 1952, 1957) while gramine is less (S upniewski and Serafinowa, 1938) or remarkably less toxic (Now a c ki, 1975). Investigation of Rýs (1976) demonstrated that increased level of gramine affected palatability of feed which resulted in decreased animal consumption.

Due to a lack of comprehensive data on the heritability of this alkaloid, the information on recombinations resulting from crosses between forms with or without gramine is not known so far. Considering the above, the assay of composition and level of alkaloids in the yellow lupine collection used to develop new breeding varieties seems to be prudent and justified.

\section{MATERIAL AND METHODS}

The material consisted of a collection of primitive and cultivated forms of yellow lupine (Lupinus luteus L.) gathered at the Plant Experiment Station Wiatrowo near Poznan. The collection comprises 178 forms of all regions of lupine origin and from countries where this species has been under cultivation.

Monographic data on lupine (B a b a cki, 1952; $\mathrm{H} \mathrm{a} \mathrm{ck} \mathrm{bar} \mathrm{th}$ and Troll, 1956) as well as the detailed study of Gladstones (1974) supplied evidence exclusively on the taxonomy of the genus 
Lupinus. M a is urian and A t a biekova (1974) introduced intraspecific taxonomy covering six botanical varieties, however, with respect to description of a few morphological characters only, viz. colour of corolla, colour of seeds and shade of green colour of vegetative organs. These characters were examined in detail by S w ięcicki (1977). The last feature was found to significantly influence the viability and productivity of yellow lupine, the other two were of lower significance. For the above and other reasons, the intraspecific taxonomy reported by M a isurian and A tabiekova (1974) was not taken into consideration in the present study.

While following the evolution of chemical processes in plants as influenced by man, it is important to compare the primitive forms, with semi-primitive forms and with local and cultivated varieties. The variation of less important morphological characters, frequently resulting from point mutations, is of minor importance in this respect.

As a result of the above study six groups of yellow lupine were separated from the collection:

1. Primitive forms collected directly from places of their origin and not yet cultivated under different environmental conditions of Central Europe. These forms were received from the most recent harvests in Portugal, Spain, Sicily and from the Near East. Places of origin pointing to the wide range of harvesting locations have been indicated. Catalogue numbers stand for places where the respective information was not available.

2. Primitive forms originating from harvests gathered long ago by Klinkowski, Lamberts and others and cultivated in many countries under different and unknown conditions. It can be assumed that cultivation under various environments affected somehow the initial genotype and brought about alternations in the alkaloid composition.

3. Bitter and cultivated local populations originating from Poland, Yugoslavia, The Netherlands, Austria and Germany.

All but one bitter breeding variety Schwako constituted unselected populations of a genotype established as a result of many years of cultivation and/or natural selection.

4. Old and recent breeding strains of low alkaloid forms from Plant Breeding Stations in Poland and the German Democratic Republic, i.e. developed and controlled by breeders in the direction of decreasing the alkaloid level in lupine.

5. Low alkaloid breeding varieties listed in State Registers for Original Varieties in ten countries or at least tested in official experimental tests.

6. Forms from spontaneous and induced mutations characteristic of 
having altered morphological traits, e.g. colour of flowers, growth rhythm, longer growing period, design and colour of seed coat.

Dividing the possessed material into the described groups facilitated orientation on the extent to which the content of alkaloids and their total level have changed due to introduction of a species into new environment, and due to long term natural selection and designed breeding work.

Chemical analyses were carried out in the Laboratory of the Plant Breeding Station Wierzenica. Size of seed samples varied approximately from 3.0 to $5.0 \mathrm{~g}$. Quantitative determination of the total alkaloid level was conducted by high sensitive colorimetric method with bromothymol blue (Skolik and Wiewiórowski, 1959). Sensitivity of the method was $2 \mu \mathrm{g}$.

Separate alkaloids were indentified employing thin layer chromatography with the use of silica gel on foil (SIL-G manufactured by Machery-Nagel). The ascending technique was carried out; the developing phase: chloroform : cyclohexane: di-ethylamine $(5: 12: 1)$ or $(5: 10: 1)$. The latter facilitated good separation of sparteine, lupinine and gramine. Spots were made visible by iodo-platinate spray ( $\mathrm{t}$ a $\mathrm{h} \mathrm{l}, 1962)$, next the plates were heated at $120^{\circ} \mathrm{C}$ for five minutes and again sprayed with iodo-platinate. Distribution of particular alkaloids in a sample was assayed by the size of spots on chromatograms. The staining sensitivity for sparteine was $0.5 \mu \mathrm{g}$, for lupinine $5,0 \mu \mathrm{g}$ and for gramine $2.0 \mu \mathrm{g}$. Due to the considerable differences in the alkaloid level in various forms, samples of different weights were used in the chromatographic separation, hence the sizes of spots were not comparable but simply served to assess the relative distribution of alkaloids within a given sample.

\section{RESULTS AND DISCUSSION}

Primitive forms of yellow lupine obtained directly from places of origin differed in morphology from the other forms, viz. dark grey shade of green colour, leaves smaller and more pubescent, small-sized seeds and a different plant habit. They differed in habit from each other, i.e. there were procumbent forms (Fig. 1) and bushy, intermediate.

The total level of alkaloids in seeds ranged from 0.54 to $3.35 \%$ (Table 1). Of the total of 41 forms analysed, only in a few the percent of alkaloids was above 2.0. The conspicuous variation in the level of alkaloids was reported many times in the literature. According to $\mathrm{Barbacki}$ (1952) besides extremely bitter forms with alkaloid level above $3 \%$, and low alkaloid varieties, intermediate forms also occur with alkaloid level below $1 \%$. Similar data were reported by $\mathrm{M}$ a is $\mathrm{u}-$ 


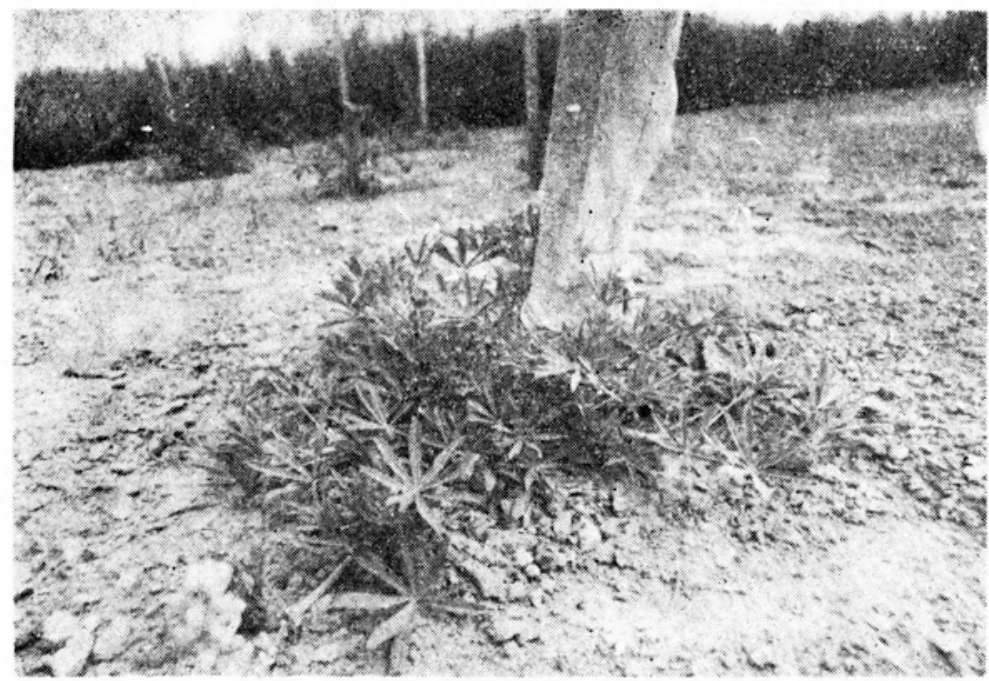

Fig. 1. A positively lodging type of Lupinus luteus L.

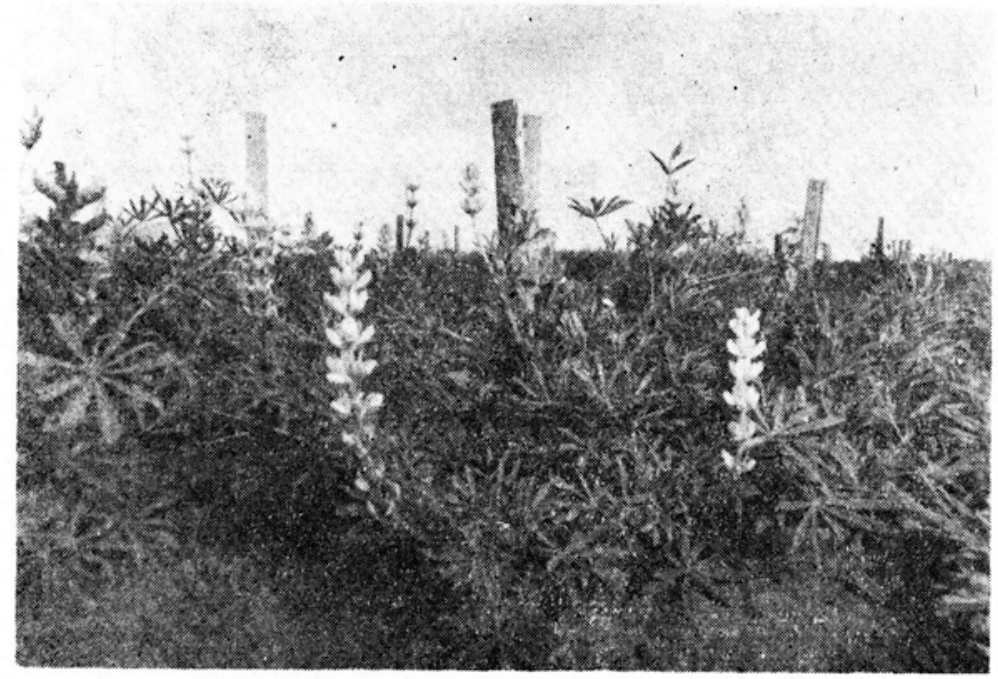

Fig. 2. A bushy form of Lupinus luteus L.

rian and Atabiekova (1974) who had found the total level to range from 1.0 to $3.5 \%$. They pointed also to the variation cited by Teiber $(0.810 \%)$ and by Braun $(0.347 \%)$. $\mathrm{Hackbarth}$ and $\mathrm{Troll}$ (1956) provided evidence the total level of alkaloids in bitter lupine varies from 0.350 to $1.550 \%$. Analysis of the reported results suggests that the conspicuous variation in alkaloid level can possibly result from different plant material of a different genotype. This suggestion is in accord with the opinion of $\mathrm{Schwarze}$ and $\mathrm{Hackbarth}$ (1957). 
Table 1

Quantitative and qualitative analysis of alkaloids in seeds of primitive yellow lupine forms collected directly frem places of origin

\begin{tabular}{|c|c|c|c|c|c|c|c|c|}
\hline \multirow[b]{2}{*}{ Item } & \multirow{2}{*}{$\begin{array}{l}\text { No of } \\
\text { sample }\end{array}$} & \multirow[b]{2}{*}{ Population } & \multirow[b]{2}{*}{ Origin } & \multirow{2}{*}{$\begin{array}{l}\text { Alkaloid } \\
\text { content } \%\end{array}$} & \multicolumn{3}{|c|}{ Composition of alkaloids } & \multirow{2}{*}{$\begin{array}{c}\text { Other } \\
\text { unidentified } \\
\text { compounds }\end{array}$} \\
\hline & & & & & gramine & lupinine & sparteine & \\
\hline 1 & 2 & 3 & 4 & 5 & 6 & 7 & 8 & 9 \\
\hline 1 & 3749 & Leotipo -1 & Portugal & 0.86 & $\mathrm{~m}$ & $\mathrm{~m}$ & $\mathrm{~h}$ & - \\
\hline 2 & 3750 & Leotipo -3 & , & 0.85 & $\mathrm{~m}$ & $\mathrm{~m}$ & 1 & - \\
\hline 3 & 3751 & Quinta dos Alfoiados & $"$ & 0.70 & $\mathrm{~m}$ & $\mathrm{~m}$ & $\mathrm{~h}$ & $\mathrm{x}_{1}, \mathrm{x}_{2}$ \\
\hline 4 & 3752 & Montalvo - 1 & $"$ & 1.34 & $\mathrm{~m}$ & $\mathrm{~h}$ & $\mathrm{~m}$ & $\mathrm{x}_{1}, \mathrm{x}_{2}$ \\
\hline$\overline{5}$ & 3753 & Montalvo - 2 & $"$ & 1.05 & $\mathrm{~m}$ & $\mathrm{~m}$ & 1 & 12 \\
\hline 6 & 3754 & Herdade de Volbom -1 & $"$ & 0.88 & $\mathrm{~m}$ & $\mathrm{~h}$ & $\mathrm{~h}$ & - \\
\hline 7 & 3755 & Herdade de Volbom $-\mathbf{2}$ & $"$ & 0.67 & $\mathrm{~m}$ & 1 & $\mathrm{~h}$ & - \\
\hline 8 & 3756 & Herdade de Volbom -3 & $"$ & 1.05 & $\mathrm{~m}$ & $\mathrm{~m}$ & $\mathrm{~m}$ & 一 \\
\hline 9 & 3757 & Quinta Grande & $"$ & 0.88 & 1 & $\mathrm{~m}$ & $\mathrm{~m}$ & - \\
\hline 10 & 3758 & Biscainhos - 1 & 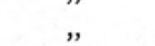 & 0.66 & $\mathrm{~m}$ & $\mathrm{~m}$ & $\mathrm{~m}$ & - \\
\hline 11 & 3759 & Biscainhos - 2 & , & 0.64 & $\mathrm{~m}$ & $\mathrm{~m}$ & $\mathrm{~h}$ & - \\
\hline 12 & 3760 & Biscainhos -3 & $"$ & 1.10 & $\mathrm{~m}$ & $\mathrm{~h}$ & $\mathrm{~m}$ & - \\
\hline 13 & 3761 & Biscainhos -5 & , & 1.30 & $\mathrm{~m}$ & $\mathrm{~h}$ & $\mathrm{~h}$ & $\mathrm{x}_{3}$ \\
\hline 14 & 3762 & Abrantes -1 & $"$ & 1.16 & $\mathrm{~m}$ & $\mathrm{~h}$ & $\mathrm{~h}$ & $\mathrm{x}_{3}$ \\
\hline 15 & 3763 & Abrantes -2 & $"$ & 0.90 & $\mathrm{~m}$ & $\mathrm{~h}$ & $\mathrm{~m}$ & $\mathrm{x}_{3}$ \\
\hline 16 & 3764 & Alvega & $"$ & 0.99 & $\mathrm{~m}$ & $\mathrm{~m}$ & 1 & - \\
\hline 17 & 3765 & Abrantes -3 & $"$ & 0.88 & $\mathrm{~m}$ & $\mathrm{~m}$ & $\mathrm{~m}$ & - \\
\hline 18 & 3766 & Abrantes -5 & $"$ & 0.67 & 1 & $\mathrm{~m}$ & $\mathrm{~h}$ & - \\
\hline 19 & 3767 & Abrantes -6 &, & 0.67 & 1 & $\mathrm{~h}$ & $\mathrm{~m}$ & - \\
\hline 20 & 3768 & Vale dos Peixes - $\mathbf{2}$ & , & 1.02 & 1 & $\mathrm{~m}$ & $\mathrm{~m}$ & - \\
\hline
\end{tabular}




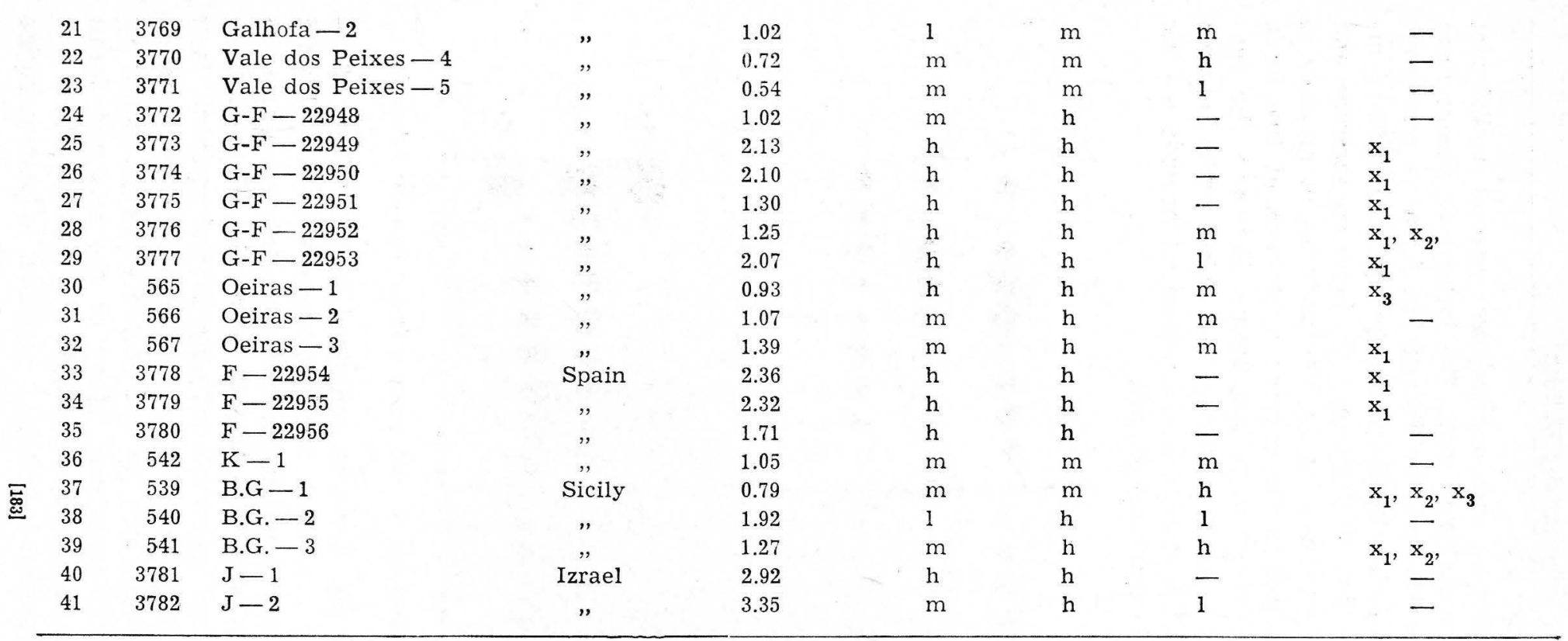

Abbreviations: $\mathrm{h}-$ high content, $\mathrm{m}-$ medium content, $\mathrm{l}-$ low content, -- absent. 
In all analysed forms gramine and lupinine were present in different ratios. The majority had sparteins as well. The latter was absent from four Portugese, three Spanish and one Palestinian form. A numerous group of forms showed additionally trace amounts of unidentified alkaloids of Rf higher than that of sparteine, viz. between lupinine and sparteine or lupinine and gramine (Fig. 3). The presence of gramine in all 41 analysed forms contradicts the current hypothesis of two basic alkaloids (lupinine and sparteine) in yellow lupine. However, the analysis of the total alkaloid level, composition and relationship between forms from different Mediterranean countries does not provide a basis for separation of specific geographical groups.

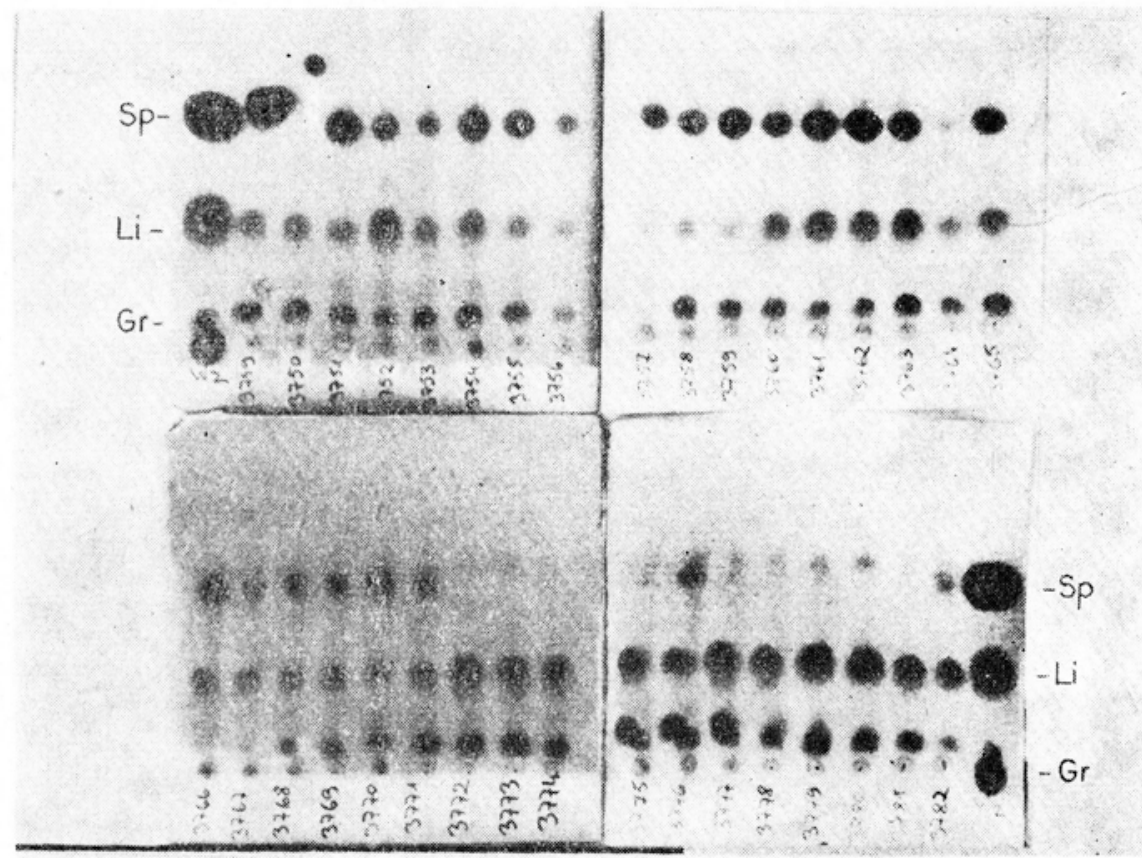

Fig. 3. Chromatogram o: alkaloids of wild growing forms Lupinus luteus L.

Primitive forms fron old harvests contained less alkaloids (0.15$-1.88 \%$ (Table2). It can be assumed that genotypes with the alkaloid level below $0.5 \%$ differ from initial forms and have developed as a result of spontaneous crosses with low-alkaloid forms. All 37 forms analysed contained lupinine and sparteine but only 17 had gramine. It is of interest to notice that in the majority of low alkaloid forms gramine was absent which can be explained by the altered genotype and/or by the different environmental conditions. Many of the analysed forms showed traces of other unidentified compounds of alkaloid nature.

A characteristic phenomenon in alkaloid evolution in yellow lupine 
is the composition of alkaloids in bitter cultivated European populations (Table 3). All but one Dutch population had no gramine, however, in all sparteine and lupinine were present. The total level of alkaloids was less differentiated in this group and ranged from 0.43 to $1.50 \%$. A comparison of data in Table 1, 2 and 3 throws some light on the reasons as to why gramine was not considered to be one of the basic alkaloids in yellow lupine up to present. It seems that investigations on primitive forms from old collections as well as investigations on bitter cultivated populations and low alkaloid forms have not included analysis of forms coming directly from places of origin.

The decline of gramine following introduction of lupine into changed environmental conditions is intriguing. Some thought should be given to the possible influence of genetic background. Considering the gradual process of alkaloid synthesis in plants it can be assumed that in spontaneous crosses between genetically different forms of yellow lupine, the synthesis of alkaloids is inhibited at various stages. T u r bin and A nochina (1973) reported changes in alkaloid relations in many yellow lupine hybrids. The above confirms the hypothesis of Now a cki (1958) on alkaloid alterations in plants, with different intensity depending on genotype. However, the decline of gramine in populations propagated under conditions of Central Europe cannot be only attributed to the introgression of foreign genotypes.

Lupinus grow in their natural habitats as overwintering annuals. The prevailing conditions during their growing season are: short day and cool weather. When Mediterranean populations are propagated in Central Europe, the daylight and temperatures are entirely different during the spring-summer growing season. Some plants fail to produce seeds, some produce few seeds and a small part yields a fairy good of seeds. We assume that a rapid elimination of some genotypes does occur. It is conceivable that the gramine character may be linked with growth habit not suitable for conditions of Central Europe.

Except for some hybrids with the Palestinian form with high alkaloid level, the level of alkaloids in the remaining breeding strains ranged from 0.032 to $0.480 \%$ (Table 4). Excluding some hybrids with the palestinian form, only a few strains had a very low level of gramine but all had lupinine and sparteine. A German strain Stamm 55 had a low total level of alkaloids $(0.032 \%)$ involving all three alkaloids.

In breeding varieties originating from nine countries the total level of alkaloids ranged from 0.030 to $0.220 \%$ (Table 5). The results indicate a distinct effect of screening on low alkaloid level. The range of alkaloid levels cited above represents a higher variation range than those described by $\mathrm{Hackbarth}$ and $\mathrm{Troll}$ (1956) and $\mathrm{Maisurian}$ and A tabiekova (1974). However, data obtained by these authors did 
Table 2

Quantitative and qualitative analysis of alkaloids in seeds of primitive yellow lupine forms from harvests and reproduced in Middle Europa in the past years

\begin{tabular}{|c|c|c|c|c|c|c|c|c|}
\hline \multirow{2}{*}{ Item } & \multirow{2}{*}{$\begin{array}{l}\text { No of } \\
\text { sample }\end{array}$} & \multirow[b]{2}{*}{ Population } & \multirow[b]{2}{*}{ Origin } & \multirow{2}{*}{$\begin{array}{l}\text { Alkaloid } \\
\text { content } \%\end{array}$} & \multicolumn{3}{|c|}{ Composition of alkaloids } & \multirow{2}{*}{$\begin{array}{c}\text { Other } \\
\text { unidentified } \\
\text { compounds }\end{array}$} \\
\hline & & & & & gramine & lupinine & sparteine & \\
\hline 1 & 2 & 3 & 4 & 5 & 6 & 7 & 8 & 9 \\
\hline 1 & 533 & Klinkowski - 1 & Portugal & 0.65 & $\mathrm{~m}$ & $\mathrm{~h}$ & $\mathrm{~h}$ & $x_{1}, x_{2}$ \\
\hline 2 & 534 & Klinkowski - 2 & $"$ & 1.22 & $\mathrm{~m}$ & $\mathrm{~h}$ & $\mathrm{~h}$ & $x_{1}, x_{2}$ \\
\hline 3 & 535 & Klinkowski - 3 & $"$ & 1.88 & $\mathrm{~m}$ & $\mathrm{~h}$ & 1 & $x_{1}, x_{2}, x_{3}$ \\
\hline 4 & 536 & Lamberts -4 & $"$ & 0.84 & $\mathrm{~m}$ & $\mathrm{~h}$ & $\mathrm{~h}$ & $\mathrm{x}_{1}, \mathrm{x}_{2}$ \\
\hline 5 & 537 & Nowacki -5 & $"$ & 0.87 & $\mathrm{~m}$ & $\mathrm{~h}$ & $\mathrm{~h}$ & $\mathrm{x}_{2}$ \\
\hline 6 & 538 & Kazimierski -6 & $"$ & 1.06 & $\mathrm{~m}$ & $\mathrm{~h}$ & $\mathrm{~h}$ & $x_{1}, x_{2}$ \\
\hline 7 & 568 & Violego & $"$ & 0.20 & - & $\mathrm{m}$ & $\mathrm{m}$ & $x_{1}, x_{2}$ \\
\hline 8 & 574 & Palmela & $"$ & 0.57 & - & $\mathrm{h}$ & $\mathrm{h}$ & 12 \\
\hline 9 & 575 & Sacarem & $"$ & 0.67 & 一 & $\mathrm{h}$ & $\mathrm{h}$ & - \\
\hline 10 & 576 & Foia & $"$ & 0.46 & - & $\mathrm{h}$ & $\mathrm{h}$ & $\mathrm{x}_{1}$ \\
\hline 11 & 577 & Lahhrina & $"$ & 0.60 & - & $\mathrm{h}$ & $\mathrm{h}$ & $\mathrm{x}_{1}$ \\
\hline 12 & 546 & Anatolia - 1 & $"$ & 1.10 & 1 & $\mathrm{~m}$ & $\mathrm{~h}$ & 1 \\
\hline 13 & 547 & Anatolia -2 & , & 1.31 & $\mathrm{~m}$ & $\mathrm{~h}$ & $\mathrm{~h}$ & $\mathrm{x}_{3}$ \\
\hline 14 & 548 & Anatolia -3 & $"$ & 1.03 & $\mathrm{~m}$ & $\mathrm{~h}$ & $\mathrm{~m}$ & $\mathrm{x}_{3}$ \\
\hline 15 & 578 & Anatolia -4 & $"$ & 0.44 & - & $\mathrm{h}$ & $\mathrm{h}$ & $\mathrm{x}_{1}^{0}$ \\
\hline 16 & 549 & Anatolia -5 & $"$ & 0.67 & 一 & $\mathrm{m}$ & $\mathrm{h}$ & $x_{3}$ \\
\hline 17 & 550 & Anatolia -6 & $"$ & 1.25 & $\mathrm{~m}$ & $\mathrm{~h}$ & $\mathrm{~m}$ & $x_{3}$ \\
\hline 18 & 551 & Anatolia -7 & $"$ & 1.05 & $\mathrm{~h}$ & $\mathrm{~m}$ & $\mathrm{~m}$ & $\mathrm{x}_{3}$ \\
\hline
\end{tabular}




\begin{tabular}{|c|c|c|c|c|c|c|c|c|c|}
\hline 19 & 597 & Anatolia -8 & & 0.15 & - & $\mathrm{m}$ & $\mathbf{h}$ & $x_{1}, x_{3}$ & \\
\hline 20 & 552 & Fus. rez. Lamberts -1 & $\boldsymbol{n}$ & 0.45 & - & $\mathrm{m}$ & $\mathrm{m}$ & - & \\
\hline 21 & 563 & Fus. rez. Lamberts - 2 & $"$ & 0.67 & - & $\mathrm{m}$ & $\mathrm{h}$ & - & \\
\hline 22 & 554 & Fus. rez. Lamberts -3 & $n$ & 0.20 & - & $\mathrm{m}$ & $\mathrm{h}$ & $\mathrm{x}_{3}$ & \\
\hline 23 & 570 & Erisiphe rez. Lamberts -1 & $"$, & 0.25 & $\mathrm{~h}$ & $\mathrm{~m}$ & 1 & $\mathrm{x}_{2}$ & : \\
\hline 24 & 583 & Fus. rez. Lamberts -4 & $"$ & 0.21 & $\mathrm{~h}$ & 1 & 1 & $\mathrm{x}_{2}$ & \\
\hline 25 & 557 & $\mathrm{BGB}-4017 \mathrm{~b}$ & $"$ & 0.52 & - & $\mathrm{h}$ & $\mathbf{h}$ & $\mathrm{x}_{3}$ & \\
\hline 26 & 558 & $\mathrm{BGB}-4015$ &, & 0.96 & - & $\mathrm{h}$ & $\mathrm{h}$ & $\mathrm{x}_{3}$ & \\
\hline 27 & 543 & Klinkowski - 2 & Spain & 1.05 & $\mathrm{~h}$ & $\mathrm{~m}$ & $\mathrm{~h}$ & - & \\
\hline 28 & 544 & Klinkowski -4 & $"$ & 1.27 & $\mathrm{~m}$ & $\mathrm{~h}$ & h & - & \\
\hline 29 & 545 & Klinkowski -5 & $"$ & 1.17 & $\mathrm{~m}$ & $\mathrm{~m}$ & $\mathrm{~h}$ & - & \\
\hline 30 & 579 & Algecivus & $"$ & 0.16 & - & $\mathrm{m}$ & $\mathrm{m}$ & - & \\
\hline 31 & 560 & BGB -3976 & $"$ & 0.79 & - & $\mathrm{m}$ & $\mathrm{h}$ & - & \\
\hline 32 & 561 & BGB -3977 a & , & 0.75 & - & $\mathrm{h}$ & $\mathrm{h}$ & $x_{3}$ & \\
\hline 33 & 562 & BGB $-3977 b$ & $"$ & 0.60 & - & $\mathrm{m}$ & $\mathrm{h}$ & - & \\
\hline 34 & 563 & $\mathrm{BGB}-3978 \mathrm{a}$ &, & 0.79 & - & $\mathrm{h}$ & $\mathbf{h}$ & $x_{1}, x_{3}$ & \\
\hline 35 & 564 & $\mathrm{BGB}-3778 \mathrm{~b}$ & $"$ & 1.03 & 1 & $\mathrm{~h}$ & $\mathbf{h}$ & $x_{1}, x_{3}$ & \\
\hline 36 & 549 & Pambino & Italy & 1.40 & - & $\mathrm{h}$ & $\mathrm{m}$ & $\mathrm{x}_{3}$ & \\
\hline 37 & 559 & BGB -3975 & $"$ & 0.59 & - & $\mathrm{m}$ & $\mathrm{h}$ & $x_{3}$ & \\
\hline
\end{tabular}

For explanation see Table 1. 
Table 3

Quantitative and qualitative analysis of alkaloids in seeds of bitter cultivated yellow lupine forms

\begin{tabular}{|c|c|c|c|c|c|c|c|c|}
\hline \multirow[b]{2}{*}{ Item } & \multirow{2}{*}{$\begin{array}{l}\text { No of } \\
\text { sample }\end{array}$} & \multirow{2}{*}{$\begin{array}{c}\text { Population } \\
\text { and/or variety }\end{array}$} & \multirow[b]{2}{*}{ Origin } & \multirow{2}{*}{$\begin{array}{l}\text { Alkaloid } \\
\text { content } \%\end{array}$} & \multicolumn{3}{|c|}{ Composition of alkaloids } & \multirow{2}{*}{$\begin{array}{c}\text { Other } \\
\text { unidentified } \\
\text { compounds }\end{array}$} \\
\hline & & & & & gramine & lupinine & sparteine & \\
\hline 1 & 2 & 3 & 4 & 5 & 6 & 7 & 8 & 9 \\
\hline 1 & 512 & Kozienice & Poland & 0.70 & - & $\mathrm{h}$ & $\mathrm{h}$ & $\mathrm{x}_{2}$ \\
\hline 2 & 513 & Złotoria & ", & 0.63 & - & $\mathrm{h}$ & $\mathrm{h}$ & $x_{2}^{2}$ \\
\hline 3 & 521 & Drobnonasienny & $"$ & 0.82 & - & $\mathrm{h}$ & $\mathrm{h}$ & $\mathrm{x}_{1}, \mathrm{x}_{2}$ \\
\hline 4 & 555 & Lubljana & Jugoslavia & 0.49 & - & $\mathrm{m}$ & $\mathrm{h}$ & $\mathrm{x}_{3}$ \\
\hline 5 & 580 & Pal & Holland & 0.59 & - & $\mathrm{h}$ & $\mathrm{h}$ & $x_{1}, x_{2}, x_{3}$ \\
\hline 6 & 581 & Bipal & $"$ & 1.50 & - & $\mathrm{h}$ & 1 & $x_{2}, x_{3}$ \\
\hline 7 & 582 & Neederland & , & 1.27 & - & $\mathrm{h}$ & $\mathrm{m}$ & $\mathrm{x}_{2}, \mathrm{x}_{3}$ \\
\hline 8 & 588 & Kolbens Vienauer & Austria & 0.74 & - & $\mathrm{m}$ & $\mathrm{h}$ & $\mathrm{x}_{3}$ \\
\hline 9 & 522 & Raddatz Frühe & Germany & 0.64 & - & $\mathrm{h}$ & $\mathrm{h}$ & $\mathrm{x}_{3}$ \\
\hline 10 & 523 & Aschersleben & , & 0.93 & - & $\mathrm{h}$ & $\mathrm{h}$ & $x_{2}, x_{3}$ \\
\hline 11 & 524 & Severiner gelbe & $"$ & 0.84 & - & $\mathrm{h}$ & $\mathrm{h}$ & $x_{2}, x_{3}$ \\
\hline 12 & 52.5 & Lüneburger gelbe & , & 0.88 & - & $\mathrm{h}$ & $\mathrm{h}$ & $x_{2}, x_{3}$ \\
\hline 13 & 526 & Schwako & $"$ & 1.05 & - & $\mathrm{h}$ & $\mathrm{h}$ & $\mathrm{x}_{1}$ \\
\hline 14 & 573 & Paulsens gelbe & $"$ & 0.43 & - & $\mathrm{h}$ & $\mathrm{h}$ & ${ }^{1}-$ \\
\hline 15 & 587 & Jahnsfelde & $"$ & 0.94 & - & $\mathrm{m}$ & $\mathrm{h}$ & $\mathrm{x}_{3}$ \\
\hline
\end{tabular}

For explanation see Table 1. 
Table 4

Quantitative and qualitative analysis of alkaloids in seeds of some yellow lupine hybrids

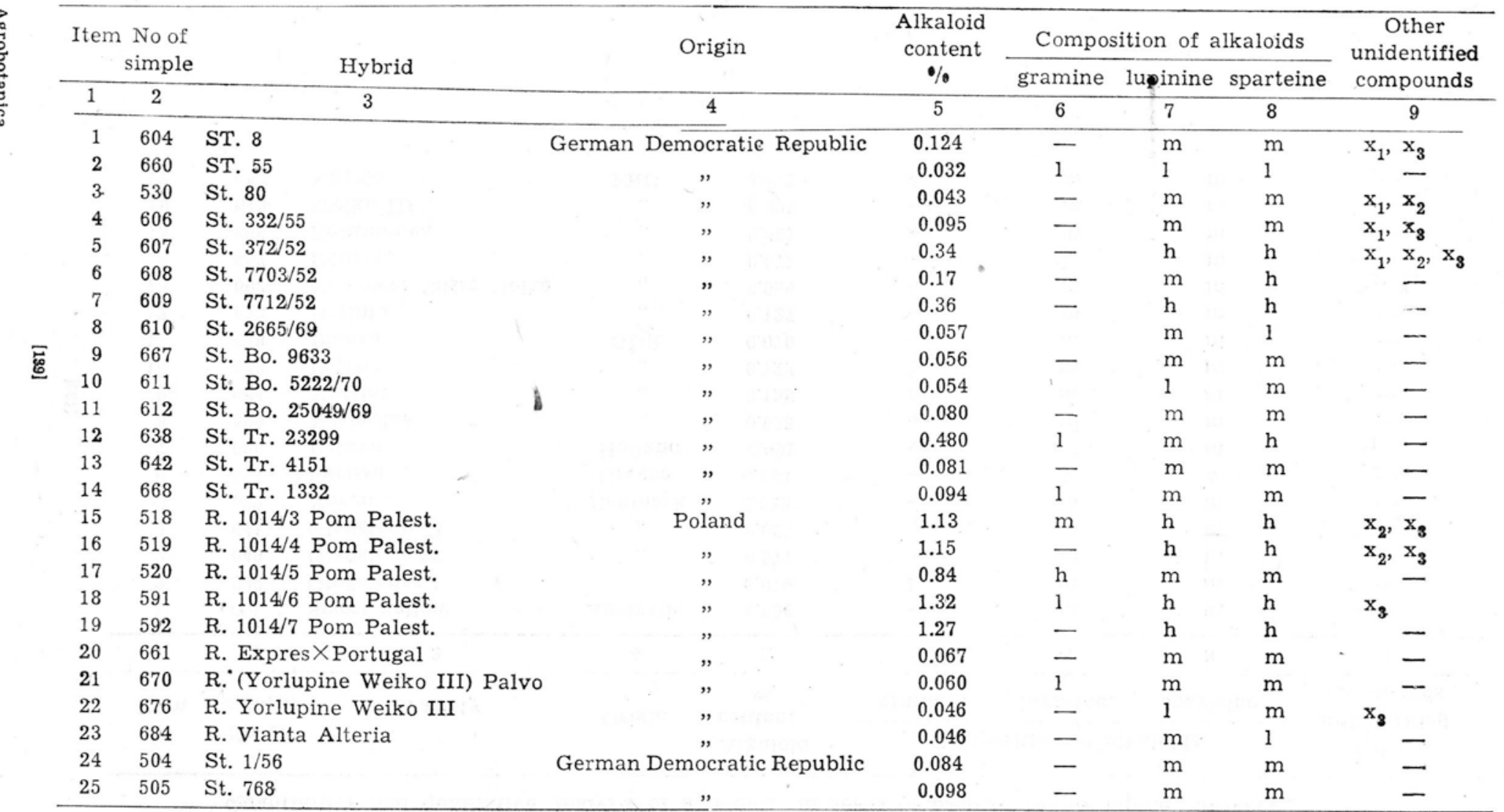

For explanation see Table 1 . 
Table 5

Quantitative and qualitative analysis of alkaloids in seeds of pasture yellow lupine cultivars

\begin{tabular}{|c|c|c|c|c|c|c|c|c|c|c|}
\hline \multirow{2}{*}{ Item } & \multirow{2}{*}{$\begin{array}{l}\text { No of } \\
\text { sample }\end{array}$} & \multirow{2}{*}{\multicolumn{2}{|c|}{ Variety }} & \multirow{2}{*}{ Origin } & \multirow{2}{*}{$\begin{array}{c}\text { Alkaloid } \\
\text { content } \\
\% \\
\end{array}$} & \multicolumn{4}{|c|}{ Composition of alkaloids. } & \multirow{2}{*}{$\begin{array}{c}\text { Other } \\
\text { unidentified } \\
\text { compounds }\end{array}$} \\
\hline & & & & & & gramine & & lupinine & sparteine & \\
\hline 1 & 2 & 3 & & 4 & 5 & 6 & & 7 & 8 & 9 \\
\hline 1 & 601 & Sweet yellow & & Australia & 0.088 & - & & $\mathrm{m}$ & $\mathrm{m}$ & - \\
\hline 2 & 639 & Gladstones-1 & ' & , & 0.079 & 1 & & $\mathrm{~m}$ & $\mathrm{~m}$ & - \\
\hline 3 & 640 & Gladstones-2 & & $"$ & 0.077 & - & & $\mathrm{m}$ & $\mathrm{m}$ & - \\
\hline 4 & 641 & Gladstones-3 & & $"$ & 0.065 & - & & $\mathrm{m}$ & $\mathrm{m}$ & - \\
\hline 5 & 622 & Neven & - & Denmark & 0.082 & - & & $\mathrm{m}$ & $\mathrm{m}$ & - \\
\hline 6 & 556 & Larissa & & Greece & 0.123 & - & & 1 & $\mathrm{~h}$ & - \\
\hline 7 & 600 & Batavo & & Holland & 0.091 & 一 & & $\mathrm{m}$ & $\mathrm{m}$ & $\mathrm{x}_{1}$ \\
\hline 8 & 599 & Yorlupine & & $"$ & 0.058 & - & & $\mathrm{m}$ & $\mathrm{m}$ & - \\
\hline 9 & 664 & Martini & $?$ & $"$ & 0.128 & $\mathrm{~m}$ & & $\mathrm{~m}$ & $\mathrm{~m}$ & - \\
\hline 10 & 663 & Palvo & & $"$ & 0.122 & 1 & & $\mathrm{~m}$ & $\mathrm{~m}$ & - \\
\hline 11 & 648 & Bianca & & GDR & 0.070 & - & & $\mathrm{m}$ & $\mathrm{m}$ & - \\
\hline 12 & 613 & Borluta & & ", & 0.127 & - & & $\mathrm{m}$ & $\mathrm{m}$ & - \\
\hline 13 & 603 & Gülzower Süsse & Gelbe & $"$ & 0.095 & - & & $\mathrm{m}$ & $\mathrm{m}$ & $x_{1}, x_{1}$ \\
\hline 14 & 657 & Refusa & & $"$ & 0.072 & - & $\cdot$ & 1 & $\mathrm{~m}$ & -1 \\
\hline 15 & 666 & Refusanova & & $"$ & 0.081 & 一 & & $\mathrm{m}$ & $\mathrm{m}$ & - \\
\hline 16 & 649 & Weiko III & & $"$ & 0.091 & 一 & & $\mathrm{m}$ & $\mathrm{m}$ & - \\
\hline 17 & 683 & Alteria & & FRG & 0.052 & - & & $\mathrm{m}$ & $\mathrm{m}$ & - \\
\hline
\end{tabular}




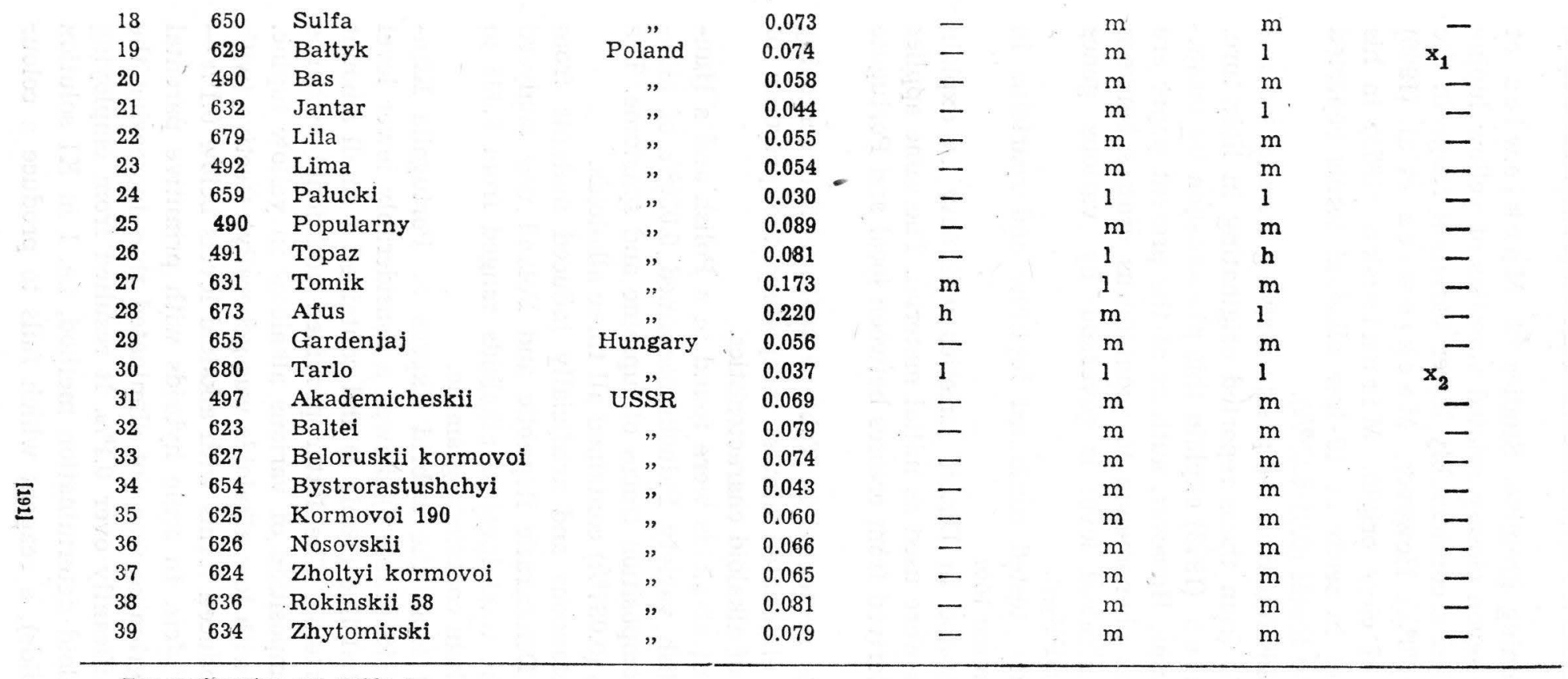

For explanation see Table 1. 
not include forms containing gramine. Studies of $\mathrm{Mackiewicz}$ et al. (1960) carried out on seven closely related varieties of yellow lupine in 1952-1956, demonstrated a considerably lower variation range in the alkaloid level $(0.050-0.070 \%)$. However, $\mathrm{M}$ a c kiewicz et al. (1960) experimented on forms of close origin. Mironienko (1975) in his analysis of alkaloid level in seeds of 19 low alkaloid forms reported broader ranges of alkaloid levels (0.01-0.39\%).

Total levels of alkaloids found in the plants deriving from collections are often much different from those reported originating in literature. $\mathrm{Turbin}$ and Anochina (1973) explain this phenomenon by incompatibility of parental forms. However, authors of the present paper are inclined to attribute this phenomenon to spontaneous crosses between forms, where the low alkaloid level is governed by various genes (dulcis, amoenus, liber and $V_{351}$ ).

All cultivated varieties tested contained lupinine and sparteine in seeds, and few some gramine too.

The presence of gramine in Dutch varieties was easy to explain because Portugese forms were used as initial material. The same applies to two Polish varieties derived from crosses between local and Portugese forms.

Moreover, the results presented in Table 5 indicate that screening for low alkaloid level eliminated almost completely the presence of unidentified compounds of alkaloid characteristics.

The lowest contents of alkaloids were found in a Polish and a Hungarian variety. The Polish variety Pałucki contained $0.030 \%$ of alkaloids and had in their composition traces of lupinine and sparteine. The Hungarian variety Tarlo $(0.037 \%)$ contained all three alkaloids.

A group of 20 spontaneous and artificially induced mutants from Australia, the German Democratic Republic and Poland was analysed separately (Table 6). The total level of alkaloids ranged from 0.055 to $1.620 \%$. Only a few of them contained gramine.

One mutant derived from the hybrid Expres $\times$ Portugalia Klinkowski-2 treated with EMS (Table 6) showed a considerably lower level of alkaloids than its initial line (Table 4) and contained a small amount of lupinine besides sparteine. The latter provided additional evidence on the alterations in composition of various alkaloids in yellow lupine.

Screening for forms with low alkaloids was generally effective (with a few exceptions). It produced forms with alkaloid levels below $0.1 \%$ governed by the gene dulcis. In some hybrids with primitive parental forms, the presence of gramine was not eliminated thus increasing the total alkaloid level significantly over $0.1 \%$. It resulted from employing by breeders a fast alkaloid determination method, i.e. I in KI solution (iodide in potassium iodide), a reagent which fails to produce a colour 
Table 6

Quantitative and qualitative analysis of alkaloids in seeds of spontaneous and induced yellow lupine mutants

\begin{tabular}{|c|c|c|c|c|c|c|c|c|}
\hline \multirow[b]{2}{*}{ Item } & \multirow{2}{*}{$\begin{array}{l}\text { No of } \\
\text { sample }\end{array}$} & \multirow{2}{*}{$\begin{array}{l}\text { Mutation and } \\
\text { its orgin }\end{array}$} & \multirow{2}{*}{$\begin{array}{l}\text { Character } \\
\text { of mutation }\end{array}$} & \multirow{2}{*}{$\begin{array}{c}\text { Alkaloid } \\
\text { content } \\
\%\end{array}$} & \multicolumn{3}{|c|}{ Composition of alkaloids } & \multirow{2}{*}{$\begin{array}{c}\text { Other } \\
\text { unidentified } \\
\text { compounds }\end{array}$} \\
\hline & & & & & gramine & lupinine & sparteine & \\
\hline 1 & 4 & 3 & 6 & 5 & 6 & 7 & 8 & 9 \\
\hline 1 & 527 & St. orange GDR & flower-colour & 0.100 & - & $\mathrm{m}$ & $\mathrm{m}$ & - \\
\hline 2 & 602 & St. RM GDR &,$\quad$, & $0 . \dot{9}$ & - & $\mathrm{m}$ & $\mathrm{m}$ & $x_{1}, x_{3}$ \\
\hline 3 & 614 & Rufus GDR & $"$, & 0.090 & - & $\mathrm{m}$ & $\mathrm{m}$ & - \\
\hline 4 & 615 & Schwefelgelbe GDR & $\therefore \quad, \quad$, & 0.068 & - & $\mathrm{m}$ & $\mathrm{h}$ & - \\
\hline 5 & 531 & St. curtus GDR & growth rhythm & 0.088 & - & $\mathrm{m}$ & $\mathrm{m}$ & $\mathrm{x}_{1}$ \\
\hline 6 & 595 & Hochwüchsig GDR & $\cdots \quad, \quad$, & 1.62 & - & $\mathrm{h}$ & 1 & $\mathrm{x}_{3}$ \\
\hline 7 & 596 & St. HE GDR & $"$ & 0.135 & - & $\mathrm{m}$ & $\mathrm{m}$ & $x_{1}, x_{3}$ \\
\hline 8 & 681 & St. $1 / 56$ GDR & $" \quad$, & 0.060 & 1 & 1 & $\mathrm{~m}$ & - \\
\hline 9 & 528 & Abfallend behaart & pod & 0.146 & - & $\mathrm{m}$ & $\mathrm{m}$ & $\mathrm{x}_{2}$ \\
\hline 10 & 532 & Coloratus II & seed design & 0.42 & - & $\mathrm{h}$ & $\mathrm{h}$ & $x_{1}, x_{2}$ \\
\hline 11 & 586 & Schwach gesichelt &,$\quad \quad$, & 1.16 & - & $\mathrm{h}$ & $\mathrm{h}$ & $\mathrm{x}_{3}$ \\
\hline 12 & 569 & Dark yellow Australia & flower-colour & 0.137 & $\mathrm{~m}$ & $\mathrm{~m}$ & $\mathrm{~m}$ & $x_{2}, x_{1}$ \\
\hline 13 & 674 & R-68-jasny Poland & " $\quad$, & 0.101 & - & 1 & $\mathrm{~h}$ & $\mathrm{x}_{3}$ \\
\hline 14 & 589 & Mutant Kl.-3 Poland & seed design & 0.059 & 1 & $\mathrm{~m}$ & $\mathrm{~m}$ & - \\
\hline 15 & 590 & Mutant Anat.-3 Poland & $" \quad$, & 0.105 & $\mathrm{~m}$ & 1 & $\mathrm{~m}$ & - \\
\hline 16 & 514 & Neko-Now. Poland & $"$ & 0.67 & - & $\mathrm{h}$ & $\mathrm{h}$ & $x_{2}, x_{3}$ \\
\hline 17 & 515 & Neko-Sw. Poland & $"$ & 0.46 & - & $\mathrm{h}$ & 1 & $x_{2}, x_{3}$ \\
\hline 18 & 562 & $\begin{array}{l}\text { Mutant Ekspr. XPortugal } \\
\text { K1.-2 }\end{array}$ & $" \quad " \quad$ & 0.040 & - & $\begin{array}{l}\text { very } \\
\text { little }\end{array}$ & $\mathrm{m}$ & - \\
\hline 19 & 633 & Mutant z $\mathrm{PW}_{4}$ Portugal & earliness & 0.060 & - & $\mathrm{m}$ & $\mathrm{m}$ & - \\
\hline 20 & 671 & Mutant z $\mathrm{PW}_{5}^{4}$ Portugal & . , & 0.085 & $\mathrm{~m}$ & $\begin{array}{l}\text { very } \\
\text { little }\end{array}$ & $\mathrm{m}$ & 一 \\
\hline
\end{tabular}

For explanation see Table 1. 
reaction with gramine at low concentrations. Therefore, the use of precise qualitative and quantitative methods in screening for new lupine varieties is of paramount importance.

\section{REFERENCES}

- B a r b a cki S., 1952. Łubin. PWRiL Warszawa.

Gladstones J. S., 1974. Lupins of the Mediterranean Region and Africa. West. Austral. Depart. of Agric. Techn. Bull., 26: 3-48.

$\mathrm{Hackbarth}$ J., Troll H. J., 1956. Lupinen als Körnerleguminosen und Futterpflanzen. Handbuch der Pflanzenzücht., 2 Auflage, P. Perey Verlag, Berlin. J a ch K., 1975. Występowanie graminy w łubinie żółtym. Hodowla Roślin, 4: 7-10.

J a ch G., J a ch K., 1976. Kolorymetryczna metoda ilościowego oznaczania graminy. Hodowla Roślin, 3: 16-18.

Mackiewicz Z., Tołloczko W., Kulikowska H., 1960. Wyniki doświadczeń odmianowych z lubinami pastewnymi w latach 1952-1956. Min. Roln., S. B., T. 5, 1-177.

Ma isurian N. A., A t a biekova A. J., 1974. Liupin. Moskwa.

Mironienko A. W., 1975. Biochimia liupina. Nauka i Technika, Mińsk.

Nowacki E., 1958. Badania nad syntezą alkaloidów w lubinie. Roczn. Nauk rol., 79-A-2: 505-529.

N ow a cki E., 1975. Gramina w łubinie żółtym. Hodowla Roślin, 5: 3-6.

Reifer J., Przeździecka J., Kleczkowska D., 1960. Chromatograficzna metoda ilościowego oznaczania alkaloidów lubinowych. Zesz. probl. Post. Nauk rol., 20: 205-214.

R y ś R., 1976. Wstępna ocena toksyczności alkaloidu graminy w lubinie żółtym. Raport nie opublikowany (Unpublished Report).

Skolik J., Wiewiórowski M., 1959. Fotometryczna mikrometoda oznaczania alkaloidów w lubinie. Rocz. chem., 33: 461.

Sparatore F., 1964. Isolamento della gramine dai semi di Lupinus luteus. Annale di Chimica, Roma, 54: 246.

St a h 1 E., 1962. Dunnschicht Chromatographie, Springer Verlag, 497-515.

$\mathrm{Schwarze}$ P., Hackbarth J., 1957. Untersuchungen über die Alkaloid-Komplexe von gelben, blauen und weissen Lupinen. Züchter, 27: 332-341.

Supniewski J. W., Serafinowa M., 1938. Bull. Intern. Acad. Polon. Sci. Cl. Med. 479.

Swięcicki W., 1977. Wplyw genotypu na plon nasion i zielonej masy pastewnego łubinu żółtego. Praca doktorska (Ph. D. Thesis), IUNG, Puławy.

Turbin N. W., Anokhina W. S., 1973. Geneticheskoe izuchennie alkaloidnosti u liupina. Dokl. Vaskhnil., No. 3:

Wiewi órowski M., Bratek D. M., 1960. Skład naturalnych mieszanek alkaloidowych łubinu wąskolistnego, źółtego i białego. Zesz. probl. Post. Nauk rol. 20: $245-250$.

Wiewiórowski M., Podkowińska H., 1967. Biogenesis of lupine alkaloids. Occurrence of gramine in Lupinus luteus. Bull. Acad. Polon. Sci., Ser. Sci. Biol., 10: 357.

Wierzchowski Z., 1952. O toksyczności łubinów pastewnych. Post. Wiedzy rol., 4: 41.

Wierzch owski Z., 1957. Zagadnienie toksyczności pasz lubinowych. Hod. Rośl. Aklim., 1-3. 
Zmienność i ewolucja kompleksu alkaloidów w łubinie żółtym (Lupinus luteus L.) w procesie udomowienia

\section{Streszczenie}

Kolekcję łubinu żóltego złożoną z 178 prymitywnych, uprawowych i hodowlanych form zbadano pod względem składu alkaloidów i ich sumy w nasionach. Część analizowanych form pochodziła bezpośrednio z miejsc pochodzenia tego gatunku tzn. z Hiszpanii, Portugalii oraz Izraela i nie była dotąd reprodukowana w odmiennych warunkach Europy Srodkowej. Analizowany materiał odznaczał się dużym polimorfizmem alkaloidów. Wbrew rozpowszechnionym poglądom, że w nasionach ł̧ubinu żółtego występuje tylko lupinina i sparteina, stwierdzono, że lubin żółty rosnący w naturalnych stanowiskach ma trzy podstawowe alkaloidy: graminę, lupininę i sparteinę. Ponadto liczne prymitywne formy zawierały śladowe ilości innych, niezidentyfikowanych alkaloidów. Okazało się, że w miarę introdukcji łubinu żółtego do Europy Srodkowej zmianom ulegały zarówno skład alkaloidów, jak i ich suma. Wyraznie. malała liczba form zawierających graminę oraz zmniejszała się suma alkaloidów nawet $u$ form nieselekcjonowanych. Na podstawie składu alkaloidów, ich wzajemnego stosunku oraz ich sumy nie można. jednak wyodrębnić specyficznych grup, związanych z miejscem pochodzenia. Hodowla krzyżówkowa połączona z selekcją na niską zawartość alkaloidów bardzo istotnie zmniejszyła ich sumę w nasionach, a także niemal całkowicie eliminowała występowanie śladowych ilości niezidentyfikowanych związków o charakterze alkaloidów. Silnie ograniczała również liczbę form zawierających graminę. Znaleziono spontanicznego mutanta zawierającego tylko sparteinę i bardzo nieznaczne ilości lupininy, o ogólnej zawartości alkaloidów $0.04 \%$. 